\author{
UNITED STATES \\ DEPARTMENT OF THE INTERIOR. \\ GEOLOGICAL SURVEY
}

\title{
EROSIONAL HAZARDS MAP OF THE ARCTIC CDAST OF THE NATIONAL PETROLEUM RESERVE--ALASKA
}

\author{
BY \\ R. W. HARTZ
}

OPEN-FILE REPORT 78-406

This report is preliminary and has not been edited or reviewed for conformity with

Geological Survey standards and nomenclature

Mento Park, California

1978 
EROSIONAL HAZARDS MAP OF THE ARCTIC COAST

OF THE NATIONAL PETROLEUM RESERVE-ALASKA

by

R. W. Hartz

This erosional hazards map evaluates rates of change in coastal morphology and on this basis categorizes land-use hazards along the Chukchi and Beaufort Sea coastal segments of NPR-A. The evaluation and the discussion that follows draw heavily upon the reports listed in the bibliography. A synthesis of these works has been combined with personal field observations made during the summers of 1976 and 1977. In areas that were not covered by previous reports or by personal observations, rates of coastal retreat have been estimated by examining single nonsequential sets of air photos and topographic maps.

This study was supported jointly by the U.S. Geological Survey and the Bureau of Land Management through interagency agreement with the National Oceanic and Atmospheric Administration as part of the Outer Continental Shelf Environmental Assessment Program (OCSEAP). David M. Hopkins participated in the study and reviewed the manuscript. Most coastal erosion takes place during late summer and autumn. Drifting snow accumulates in the lee of beach bluffs during winter and the resulting snow drifts tend to persist on the beaches through June and into July. Where snow is lacking, mud slumps and flows, caused by thawing permafrost, regrade the coastal bluffs and partly cover the narrow mainland beaches. Lunar tides are small, persisting sea ice minimizes wave fetch, and the barometric high pressure systems of early summer keep sea level low, so that the small waves of June and July wash only the lowest part of the 
beach. During late summer and autumn, however, the weather is dominated by the passage of cyclonic low pressure systems, permitting sea level to rise. The remaining snow and much of the slumped material is quickly removed from the beach. The rise of sea level in response to low barometric pressure may be augmented by a setup due to onshore winds, resulting in storm surges 3 to $3.5 \mathrm{~m}$ above normal sea level (Hume and Schalk, 1967; Reimnitz, personal commun., 1977). Yearly rates of coastal retreat and longshore sediment transport are (in some cases) greatly accelerated during such storm surges.

In general, the entire coastline of NPR-A from Icy Cape to the Colville River delta may be characterized as thermoerosional, although localized accretionary segments are found on certain spits, bars, and river deltas such as the spit at Point Franklin and the Meade River delta. The Chukchi Sea and Beaufort sea coastlines have contrasting erosional regimes.

The Chukchi Sea erosional regime extends from Icy Cape to Point Barrow. It forms a linear, northeast-southwest trending coast with few large embayments. The coastline of the Chukchi regime is controlled by longshore sediment transport to the northeast with localized reversals to the southwest occurring from Icy Cape to Pingorarok Hill and from Point Franklin to Peard Bay. Longshore transport is the dynamic force responsible for the construction of the barrier island which form Kasegaluk Lagoon and the offshore bar system that extends from Icy Cape to Skull cliff. Littoral drift may be augmented by southwest to westerly storm surges that can move as much sediment in one event as is moved during the entire open-water season under normal conditions. These 
barriers and offshore bars tend to dampen wave attack on the mainland coastal bluffs that are as high as $25 \mathrm{~m}$, but most bluffs are in the 7 to $8 \mathrm{~m}$ range. The coastal bluffs are predominantly composed of sand and pebbly sand of the Gubik Formation, in places underlain by Cretaceous bedrock. Bedrock outcrops, where present, are relatively resistant to wave attack and tend to form a straight coastline. Coastal segments lacking bedrock outcrops erode readily when subjected to wave action and they provide the clastic sediments necessary for the construction of barrier islands offshore bars, and mainland beaches.

The Beaufort Sea erosional regime extends from Point Barrow to the Colville River delta and produces a deeply embayed coastline that trends northwest-southeast. Longshore sediment transport is generally to the northwest with localized reversals in littoral drift occurring in association with some embayments such as Smith Bay and Pogik Bay. A large portion of the Beaufort Sea coast is exposed to direct wave attack due to its orientation (i.e., the angle at which it receives incoming waves) and the absence of barrier islands and extensive offshore bar systems. Where barrier islands are present they afford little protection for the mainland coast because they enclose lagoons wide enough to permit considerable wave fetch. The mainland bluffs are as high as $10 \mathrm{~m}$, but most are in the 2 to $4 \mathrm{~m}$ range. They consist of silt, fine sand, and peat of the Gubik Formation; bedrock is not exposed along the Beaufort Sea coast. The fine grained, ice-rich sediments of these coastal bluffs erode rapidly but provide little sediment coarse enough to remain on the beach. 
Rates of coastal retreat are particularly rapid along the Beaufort Sea coast. During the ice free period from July to October even small waves erode a large portion of the coastal bluffs. Retreat of the Chukchi Sea coast, though fairly rapid, tends to be limited to major storms in the ice-free season and is moderated by the considerable supply of sand and gravel furnished by erosion of the coastal bluffs and made available for beach nourishment. Where present, bedrock outcrops also tend to retard bluff retreat along the Chukchi sea coast. The Beaufort Sea beaches are much narrower and erosion of the coastal bluffs yields little sand and gravel; thus beaches tend to be thin and undernourished. During periods of low barometric pressure, sea level commonly risesabove the beaches and even small waves can vigorously assault the coastal bluffs. The exposed frozen silt and fine sand is quickly thawed, eroded, and removed, commonly forming a thermal niche which can undercut the bluffs for a distance of several meters. When frost cracks, along the axes of the ice wedges, are intersected by the thermal niche huge blocks of tundra up to $6 \mathrm{~m}$ wide may collapse into the swash zone. In exposed areas such as Cape Halkett, Drew Point, and Cape Simpson, where wave attack can come from any one of several directions, this process accounts for phenomenal rates of coastal retreat, as much as $25 \mathrm{~m}$ per year (Leffingwell, 1919).

When considering coastal construction sites, careful evaluation of the erosional hazards under normal and catastrophic conditions must be made in order to avoid costly repairs or relocations. Storm surges along the Chukchi Sea coast have raised sea level $3 \mathrm{~m}$ or more, inundating and undermining the foundations of two 5,000-gallon 
oil tanks that were installed during the mid-50's as part of the now abandoned Icy Cape DEW-Line site. These oil tanks now lie on the active beach only a few meters from the swash zone and serve as a grim reminder of inadequate considerations of erosional hazards. 


\section{Bibliography}

Hayes, M. O., and Numedal, Dag, 1977, Tentative morphologic classification of Barrier Islands along the Arctic coast of Alaska: Chukchi-Beaufort Sea OCSEAP Mtg., Barrow, Informal Rept. RY-59, Task-DY, $47 \mathrm{p}$.

Hume, J. D., and Schalk, M., 1967, Shoreline processes near Barrow, Alaska; a comparison of the normal and the catastrophic: Arctic, v. 20 , no. 2 , p. 86-103.

Hume, J. D., Schalk, M., and Hume, P. W., 1972, Short term climate changes and coastal erosion, Barrow, Alaska: Arctic, v. 25, no. 4, p. 272-278.

Leffingwell, E. DeK., 1919, The Canning River region northern Alaska: U.S. Geol. Survey Prof. Paper 109.

Lewellen, R. I., 1970, Permafrost erosion along the Beaufort Sea coast: [Pub. of the author] P.O. Box 1068, Littleton, CO, 25 p. 1973, The occurrence and characteristics of nearshore permafrost in northern Alaska, p. 131-136, in Permafrost, the North American Contribution to the Second International Conference: Washington, DC, Natl. Acad. Sci. 1974, Offshore permafrost of Beaufort Sea, Alaska, in Reed, J. C., and Sater, J. E., eds., Arctic: Arctic Inst. North America. 1977, A study of Beaufort Sea coastal erosion in northern Alaska: Arctic Inst. North America, RU-407, Final Rept., 24 p. McCarthy, G. R., 1953, Recent changes in shoreline near Point Barrow, Alaska: Arctic, v. 6, p. 45-51. 
Moore, D. G., 1964, Acoustic-reflection reconnaissance of continental shelves; eastern Bering and Chukchi Seas, in Miller, R.'L., ed., Papers in Marine Geology, Shepard Commemorative Volume: New York, MacMillan Co.

Rex, R. W., 1964, Arctic beaches, Barrow, Alaska, p. 384-400, in Miller, R. L., ed., Papers in Marine Geology: New York, MacMillan Co.

Wiseman, w. J., Jr., Short, A. D., and others, 1973, Alaskan Arctic coastal processes and morphology: Louisiana State Univ., Coastal Studies Inst., Tech. Rept. No. 149. 